\title{
EFEKTIVITAS PREEMTIF KETAMIN SUBDOSIS DALAM MENGURANGI KEBUTUHAN OPIOID INTRAOPERATIF DAN WAKTU EKSTUBASI
}

\author{
Rizky Bagoes Septiyawan $^{1 *}$, Dedi Susila ${ }^{2}$, Soni Sunarso ${ }^{3}$ \\ 1 RSUD Dr. Soetomo
}

Corresponding author:

Rizky Bagoes Septiyawan

RSUD Dr. Soetomo

Email: alamatsurelcoauthor.com

\section{Article Info:}

Dikirim: 08 Juni 2021

Ditinjau: 08 Mei 2021

Diterima: 10 November 2021

DOI:

https://doi.org/10.33475/jikmh.v7i2.21

\begin{abstract}
Surgical perioperative management is updated to support the outcome of postoperative patients. The concept of longer preoperative fasting time, cleansing of the digestive tract, and re-nutrition after 35 days after surgery has begun to be abandoned which is then formulated into a new protocol called ERASmeliputi preoperative counseling, nutrition optimization, use of anesthesia and analgesi drugs according to standards, and early mobilization using the concept of preemptive analgesia. The use of low doses of ketamine for postoperative analgesia has evolved in part because of nmda's antagonistic properties that reduce central sensitization and opioid tolerance. The study aimed to study the effects of low-dose ketamine as a preemtive and evaluate the total need for opiods, as well as the length of time of extubation with the experimental study of single blind. Patients with label $A$ received preemptive ketamine subdose therapy while label $B$ received standard perioperative analgesia therapy. Analgesia in groups $A$ and $B$ is given before surgery. Treatment control is done with single blind control i.e. the patient does not know the type of drug given. Comparing the amount of fentanyl in the control group and treatment in this study found a significant difference $(p=0.044)$. The old comparison of extubation in both groups obtained a significant $p$ value $(<0.0001)$. Preemptive administration of ketamine subdosis effectively decreases the amount of fentanyl administration used during surgery and shortens the extubation time.
\end{abstract}

Keywords:Preemptive; Ketamin subdose; Fentanil; Extucation Time.

\begin{abstract}
Abstrak
Penatalaksanaan perioperatif bedah mengalami pembaruan untuk menunjang outcome pasien pascaoperasi. Konsep waktu puasa pra operasi yang lebih lama, pembersihan saluran pencernaan, dan pemberian nutrisi kembali setelah 3-5 hari setelah operasi sudah mulai ditinggalkan yang kemudian diformulasikan ke dalam protokol baru disebut ERASmeliputi konseling pra operasi, optimalisasi nutrisi, penggunaan obat anestesi dan analgesi sesuai standard, serta mobilisasi dinimenggunakan konsep preemptive analgesia. Penggunaan ketamin dosis rendah untuk analgesia postoperatif telah berkembang sebagian karena sifat antagonistik NMDA yang mengurangi sensitisasi sentral dan toleransi opioidnamunmasih kontroversial. Penelitian ini bertujuan untuk mempelajari efek ketamin dosis rendah sebagai preemtif dan mengevaluasi total kebutuhan opiod, serta lama waktu ekstubasidenganpenelitian eksperimental single blind. Pasien dengan label A mendapat terapi preemptive ketamin subdose sedangkan label B mendapat terapi analgesia standar perioperative. Analgesia pada kelompok A dan B diberikan sebelum operasi. Kontrol perlakuan dilakukan dengan single blind control yaitu pasien tidak mengetahui jenis obat yang diberikan. Komparasi jumlah fentanil pada kelompok kontrol dan perlakuan pada penelitian ini didapatkan perbedaan signifikan $(\mathrm{p}=0,044)$. Komparasi lama ekstubasi pada kedua kelompok didapatkan nilai $\mathrm{p}$ yang signifikan $(<0,0001)$. Pemberian preemptive ketamin subdosis efektif menurunkan jumlah pemberian fentanil yang digunakan selama operasi dan memperpendek waktu ekstubasi.
\end{abstract}

Kata Kunci: Preemptive;KetaminSubdose; Fentanil; Waktu Ekstubasi 


\section{PENDAHULUAN}

Penatalaksanaan perioperatif bedah mengalami pembaruan untuk menunjang outcome pasien paska operasi. Konsep kebutuhan waktu puasa preoperasi yang lebih lama, pembersihan saluran pencernaan, dan pemberian nutrisi kembali setelah 3-5 hari setelah operasi sudah mulai ditinggalkan. Perubahan-perubahan ini yang kemudian diformulasikan ke dalam protokol baru yang disebut ERAS (Enhanced Recovery After Surgery). ERASmerupakan penatalaksanaan perioperasi yang berbasis multimodal untuk mendapatkan pemulihan segera kondisi pasien setelah dilakukan operasi (Vuyk et al., 2015).

Kunci utama pada protokol ERAS meliputi edukasi preoperasi, optimalisasi nutrisi, penggunaan obat anestesi dan analgesi multimodal, serta mobilisasi dini. Untuk menunjang konsep ERAS tersebut dibutuhkan konsep multimodal analgesia baik. Opioid merupakan elemen analgesia penting intraopertif, namun opioid memiliki efekmenurunnya sensitifitas nafas terhadap $\mathrm{CO} 2$ dan memperlama efek sedasi karena sinergisitas dengan obat sedasi. Efek tersebut bertolak belakang dengan konsep dasar ERAS sehingga penggunaan obat anesthesia yang dapat menurunkan kebutuhan opioid intraoperatif (Vuyk et al., 2015).

Ketamin telah diakui sebagai agen anestesi intraoperatif. Ketamin telah banyak dikembangkan Komparasi lama ekstubasi pada kedua kelompok didapatkan nilai p yang signifikan $(<0,0001)$. Pemberian preemptive ketamin subdosis efektif menurunkan jumlah pemberian fentanil yang digunakan selama operasi dan memperpendek waktu ekstubasi penggunaannya sebagai preemptive analgesia. Preemptive analgesia bertujuan meminimalkan rasa nyeri intraoperatif dengan mencegah sensitisasi sentral sebelum irisan. Setelah pembentukan sensitisasi sentral karena kerusakan jaringan akibat pembedahan, nyeri dapat bertahan sampai pascaoperasi dan berkepanjangan sehingga dibutuhkan waktu tambahan untuk perbaikan. Namun, jika diberikan preemptive analgesia sebelum pembedahan maka sensitisasi sentral akan ditekan dan mencegah hyperanalgesia pascaoperasi. Di sisi lain, jika hanya diberikan pengobatan analgesik pascaoperasi, sensitisasi sentral yang dipicu oleh pembedahan akan tetap (Vuyk et al., 2015).

Peran reseptor N-Methyl-D-Aspartate sangat penting dalam proses nyeri setelah cedera akut. Peran reseptor NMDA dalam modulasi nyeri nosiseptif (misalnya nyeri pembedahan) telah manfaat klinis baru pada antagonis reseptor NMDA seperti yang terjadi pada mekanisme kerja ketamin. Ketamin berbeda dari kebanyakan obat lain yang digunakan untuk menginduksi anestesi karena memiliki efek analgesia yang signifikan. Ada beberapa bukti bahwaketamin menempati reseptor opioid di otak dan sumsum tulang belakang, hal ini dapat menjelaskan beberapa efek analgesik. Ketamin dosis rendah (didefinisikan sebagai dosis bolus kurang dari $2 \mathrm{mg} / \mathrm{kg}$ bila diberikan secara intramuskular atau kurang dari 1 $\mathrm{mg} / \mathrm{kg}$ bila diberikan melalui intravenal atau epidural) sebagai penambah opioid atau anestesi lokal dapat memainkan peran penting dalam pencegahan nyeri. (Motov et al., 2015).

Penelitian ketamin sebagai preemptif berkembang sampai dimunculkan dosis baru untuk menghindari efek tidak nyaman dari ketamin yaitu terjadinya fenomena nightmare yang terjadi pada pemberian ketamin. Ketamin intravena sub-disosiatif yang diberikan pada $0,3 \mathrm{mg} / \mathrm{kg}$ memberikan efektivitas analgesik dan keamanan yang jelas sebanding dengan morfin intravena dalam pengobatan jangka pendek nyeri akut di UGD. Meningkatnya penggunaan ketamin subdosis untuk preemtif telah berkembang sebagian 
karena sifat antagonistik NMDA-nya mengurangi sensitisasi sentral dan toleransi opioid. Efek menurunnya toleransi opioid dan pengurangan sensitisasi sentral bermanfaat pada proses ekstubasi. Penggunaan total opioid yang menurun dan manajemen analgesia yang adekuat sesuai yang konsep ERAS (Motov et al., 2015).

Saat ini Penggunaan Manajemen nyeri pasca operasi dengan opioid sering menyebabkan efek samping seperti mual dan muntah. Ketamin dapat memberikan analgesia yang lebih baik dengan efek samping yang lebih sedikit. Sebuah tinjauan literatur menyimpulkan bahwa peran ketamin, sebagai komponen analgesia perioperatif, masih kontroversial. Penelitian ini bertujuan untuk mempelajari efek ketamin subdosis sebagai preemptive dan mengevaluasi total kebutuhan opiod, serta lama waktu ekstubasi.

\section{METODE}

\section{Jenis dan Rancangan Penelitian}

\section{Jenis Penelitian}

Jenis penelitian ini yaitu penelitian eksperimental. Pasien yang akan menjalani operasi elektif akan diberikan label A dan B. Pasien dengan label A mendapat terapi preemptive ketamin subdose sedangkan label B mendapat terapi analgesia standar perioperative. Analgesia baik pada kelompok A dan B diberikan sebelum dilakukan operasi. Kontrol pemberian perlakuan dilakukan dengan single blind control yaitu pasien tidak mengetahui jenis obat yang diberikan. Desain prospektif yaitu yaitu dengan menghitungtotal kebutuhan opioid durante operasi dan waktu extubasi pasca operasi telah lulus kaji etik dilampirkan pada saat pengiriman artikel.

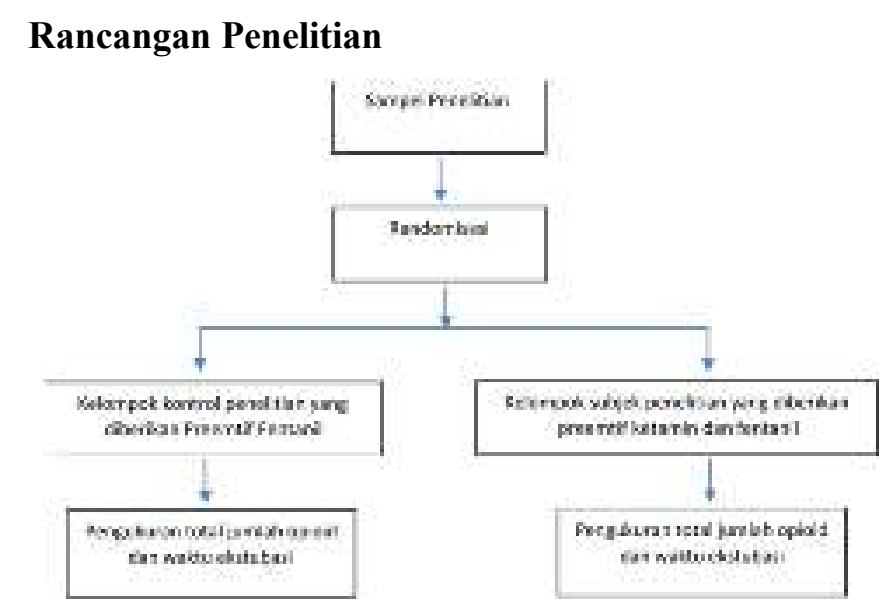

Gambar 1. Rancangan Penelitian

\section{Tempat dan Waktu Penelitian}

Penelitian ini dilakukan di RSUD Dr Soetomo pada bulan Maret-Mei 2020

\section{Populasi, Sampel, dan Teknik Pengambilan Sampel Populasi}

Pasien dewasa yang akan menjalani operasi elektif dengan anestesi umum di RSUD Dokter Soetomo pada tahun 2020 .

\section{Sampel}

Pasien dewasa yang akan menjalani operasi elektif dengan anestesi umum di RSUD Dokter Soetomo pada tahun 2020 dan bersedia untuk menjadi subjek penelitian

\section{KriteriaInklusi}

1. Usia 21 sampai dengan 60 tahun.

2. Operasi dengan derajat nyeri sedang yang dilakukan secara elektifatau terencana

3. Pasien dengan PS ASA 1 - 2.

4. Menggunakan teknik pembiusan anestesi umum (general anaesthesia)

5. Bisa berkomunikasi dengan baik, tidak tuli, tidak bisu, tidak retardasi mental dan tidak pikun. 
6. Pasien rawat inap yang dilakukan tindakan bedah elektif di RSUD dr.Soetomo, Surabaya dengan lama perawatan post operatif di ruangan lebih atau sama dengan 1 kali 24 jam.

7. Penderita atau keluarga bersedia menandatangani lembar persetujuan(informed consent) untuk ikut penelitian

\section{Kriteria Eksklusi}

1. Pasien rawat jalan

2. Pasien memiliki gangguan jantung, liver dan renal yang berat

3. Pasien sedang mengalami penyakit kelainan darah

4. Mempunyai Alergi terhadap variabel independen

5. Obesitas $(\mathrm{BMI}>30)$

\section{Besar Sampel}

$$
n=\frac{2 \delta(Z \alpha+Z \beta)^{2}}{\left(\mu_{1}-\mu_{2}\right)^{2}}
$$

\section{Keterangan:}

$\mathrm{n}=$ besar masing-masing kelompok sampel

$\delta=$ standar deviasi

$\alpha=$ simpangan rata-rata daritabeldistribusi $\mathrm{Z}$ untuk $\alpha=0,05$, maka $Z \alpha=1.96$

$\beta=$ power test, ditetapkan peneliti $\beta=0$.

10 ; maka $Z \beta=1,282$

$\mu 1=$ rata-rata kelompok yang diberi preemptive ketamin dan fentanyl

$\mu 2=\quad$ rata-rata kelompok yang diberikan preemptive fentanyltunggal

Didapatkan sampel penelitian 13 sampel untuk masingmasing kelompok, dengan mengingat kemungkinan drop out pasien sebanyak $20 \%$, maka dilakukan pengambilan sampel sebanyak 15 pasien untuk masing - masing kelompok.Sampel penelitian kami adalah pasien yang menjalani operasi elektif yang menggunakan anestesi umum di RSUD dr. Soetomo Surabaya.

\section{Teknik Pengambilan Sampel}

Teknik pengambilan sampel dengan simple random sampling yaitu setiap sampel dipilih secara acak dan setiap individu memiliki kesempatan yang sama untuk dipilih menjadi subjek penelitian. Subjek penelitian kemudian diberikan label A dan B, label A untuk pasien yang mendapat preemptive ketamin subdose dan label B pasien yang mendapat terapi standar.

\section{Variabel Penelitian}

\section{Variabel Terikat}

1. Kebutuhan total Opioid durante operasi

2. Lama waktu ekstubasi

\section{Variabel Bebas}

1. Preemptive Ketamin Subdose

\section{Prosedur Penelitian}

ProsedurUmum:

1. Setiap pasien atau keluarga harus memberikan persetujuan untukdisertakan dalam penelitian ini, setelah mendapatkan penjelasan daripeneliti dan membaca tulisan informasi tentang penelitian, kemudianmenandatangani informed consent. Penjelasan disampaikan denganbahasa awam yang akan dimengerti oleh penderita dan keluarganya.

2. Semua pasien yang diikutsertakan pada penelitian ini tetapmendapatkan perawatan dan penanganan yang sesuai dengan standarpelayanan medis.

3. Penderita dan keluarga tidak dikenakan biaya dalam penelitian ini.

4. Bila terdapat efek nyeri ataupun efek samping lain yang timbul akan dilakukan penanganan yang sesuai dengan standar pelayanan medis.

Prosedur sebelum diberikan pelakuan: 
1. Penjelasan kepada pasien dan keluarga mengenai puasa makan dan minum 88 jam sebelum operasi, dapat minum cairan bening 2 jam sebelum operasi.

2. Penjelasan kepada keluarga pasien mengenai prosedur anestesi umumyang akan dilakukan.

\section{Cara Pengolahan dan Analisis Data}

Data yang telah dikumpulkan akan di catat dan di tabulasi. Proses Analisa data akan menggunakan SPSS 22.0. Nilai $\mathrm{P}<0,05$ dianggap signifikan secara statistik. Seluruh data akan di rangkum menggunakan statistic deskriptif (mean dan setandar deviasi untuk variabel kuantitatif serta jumlah dan prosentase untuk nilai kuantitativ). Untuk menilai hubungan ketamin preemtif terhadap total kebutuhan opioid digunakan uji $\mathrm{T}$ test tidak berpasangan bila distribusi data normal, bila distribusi data tidak normal digunakan uji mann whitney, Begitu juga untuk menilai hubungan ketamin preemtif terhadap lama waktu ekstubasi.

\section{Kriteria putus uji :}

1. Data penelitian tidak lengkap

2. Terjadi penyulit selama operasi yang menyebabkan terganggunya hemodinamik

3. Mengalami komplikasi yang membahayakan (reaksi alergi, mual, muntah hebat) akibat terapi yang diberikan.

4. Penderita atau keluarga menarik diri dari keikutsertaannya.

\section{Kerangka Operasional Penelitian}

Kerangka operasional penelitian untuk menganalisis mengetahui efektivitas preemptive ketamin subdose untuk menurunkan total kebutuhan opioid durante operasi dan waktu extubasi pasca operasi adalah sebagai berikut :

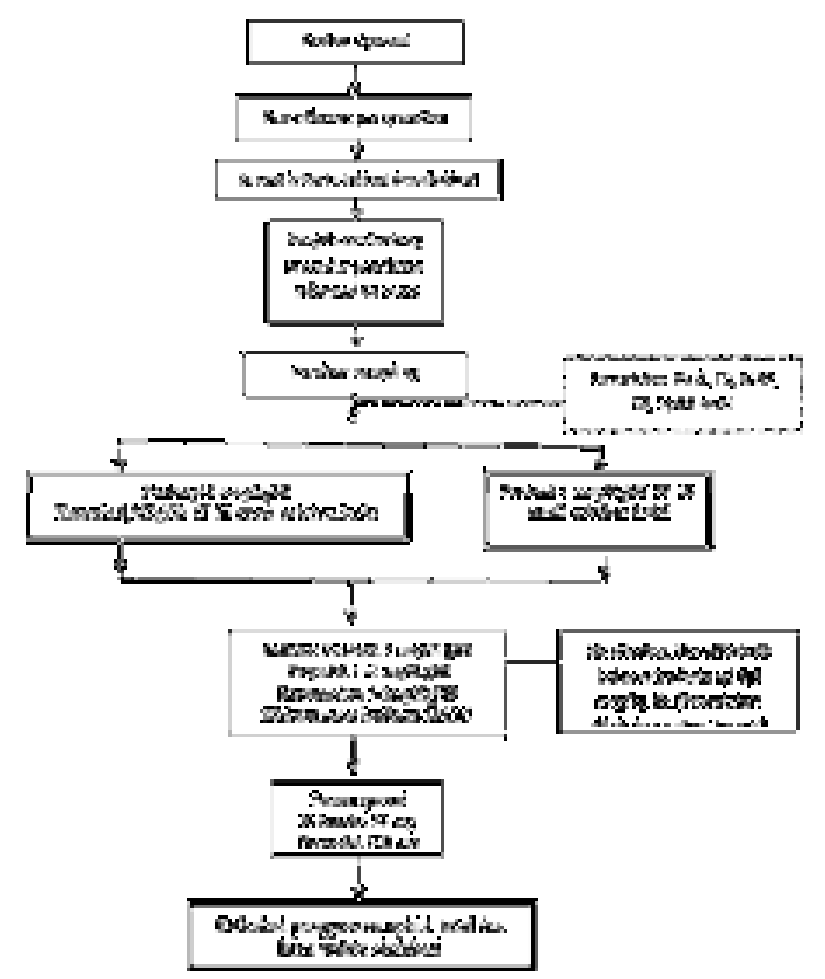

Gambar 2. KerangkaPenelitian

\section{HASIL DAN PEMBAHASAN}

Data yang dikumpulkan terdiridari data karakteristik meliputi jenis kelamin, usia, IMT, lama operasi, dan ASAskor. Data demografi jenis kelamin ditampilkan dalam bentuk tabel frekuensi.Selain data Karakteristik, setiapsampel juga akan dicatat total pemberian Fentanil dan waktu ekstubasi.

\section{Karakteristik Subyek Penelitian}

Karakteristik 30 sample yang dikumpulkan selama proses penelitian yang dilakukan pada bulan Maret - Mei 2020 akan disajikan pada tabel 1 Pada penelitian ini, sebagian besar pasien pada kelompok kontrol maupun perlakuan berjenis kelamin laki-laki. Rata-rata usia pada kelompok kontrol lebih rendah dibanding kelompok perlakuan. Rata-rata IMT pada kelompok kontrol lebih besar dibanding kelompok perlakuan. Namun tidak ada 
perbedaan jenis kelamin, usia, dan IMT yang signifikan pada kedua kelompok ( $\mathrm{p}=1,000 ; \mathrm{p}=0,836 ; \mathrm{p}=0,208)$. Berdasarkan tabel 1, sebagian besar sampel pada kelompok kontrol maupun perlakuan memiliki PS-ASA 1 (53,3\%). Tidak didapatkan perbedaan PS- ASA yang signifikan antara keduakelompoktersebut $(\mathrm{p}=1,000)$. Lama operasi antara kelompok kontrol dan perlakuan juga tidak berbeda secara signifikan $(\mathrm{p}=0,368)$ dan ditampilkan pada tabel 1. Dengan demikian, kedua kelompok tersebut memiliki anggota sampel yang homogen.

Tabel 1 Karakteristik demografik (jenis kelamin) sampel

\begin{tabular}{lccc}
\hline Variabel & $\begin{array}{c}\text { Kontrol } \\
(\mathrm{n}=15)\end{array}$ & $\begin{array}{c}\text { Perlakuan } \\
(\mathrm{n}=15)\end{array}$ & $\begin{array}{c}\text { Nilai } \\
\mathrm{p}\end{array}$ \\
\hline Jenis kelamin & $40,73(14,29)$ & $41,97(15,42)$ & 0,836 \\
\hline $\begin{array}{l}\text { Laki-laki, } \mathrm{n} \\
(\%)\end{array}$ & $9(60,0 \%)$ & $8(53,3 \%)$ & 1,000 \\
\hline $\begin{array}{l}\text { Perempuan, } \\
\mathrm{n}(\%)\end{array}$ & $6(40,0 \%)$ & $7(46,7 \%)$ & \\
\hline $\begin{array}{l}\text { ASA Skor } \\
\text { ASA 1 }\end{array}$ & $8(53,3 \%)$ & $8(53,3 \%)$ & 1,000 \\
$\quad$ ASA 2 & $7(46,6 \%)$ & $6(46,6 \%)$ & \\
\hline $\begin{array}{l}\text { Lama operasi } \\
\text { (menit) }\end{array}$ & $155(75-175)$ & $165(60-175)$ & 0.368 \\
\hline Usia (tahun) & $40,73(+14,29) 41,87(+15,42)$ & 0,836 \\
\hline IMT $\left(\mathrm{kg} / \mathrm{m}^{2}\right)$ & $26,54(+2,12)$ & $25,53(+2,17)$ & 0,208 \\
\hline
\end{tabular}

\section{Komparasi Jumlah Fentanil pada Kelompok}

\section{Kontrol dan Perlakuan}

Komparasi jumlah fentanil yang digunakan selama operasi pada kelompok kontrol dan perlakuan yang diukur tiap 15 menit hingga menit ke-180 disajikan pada tabel 2 Pada penelitian ini, didapatkan perbedaan jumlah fentanil yang signifikan $(p=0,044)$. Pada kelompok Kontrol didapatkan rata-rata penggunaan Fentanil $92 \mathrm{mcg}$ dengan SD 28,3. Sedangkan pada kelompok Perlakukan didapatkan rata-rata penggunaan $71,3 \mathrm{mcg}$ dengan SD 25,1 .
Tabel 2. Jumlah Fentanil pada kelompok kontrol dan perlakuan

\begin{tabular}{|c|c|c|c|c|c|}
\hline \multirow{2}{*}{ Variabel } & \multicolumn{2}{|c|}{ Kontrol(n=15) } & \multicolumn{2}{|c|}{$\begin{array}{c}\text { Perlakuan( } \\
n=15)\end{array}$} & \multirow[t]{2}{*}{$\begin{array}{l}\text { Nilai } \\
\text { p }\end{array}$} \\
\hline & Mean & SD & Mean & SD & \\
\hline $\begin{array}{c}\text { Total } \\
\text { Fentanil } \\
(\mathrm{mcg})\end{array}$ & 92,0 & 28,3 & 71,3 & 25,1 & $0,044 *$ \\
\hline
\end{tabular}

\section{Komparasi Lama Ekstubasi pada Kelompok Kontrol dan Perlakuan}

Komparasi lama ekstubasi pada kedua kelompok dapat dilihat pada tabel 3 berikut. Dari data tersebut didapatkan nilai p yang signifikan $(<0,0001)$. Pada kelompok kontrol didaparkan rata-rata waktu ekstubasi 9,9 menit dengan nilai minimal 9 menit dan nilai maksimal 11 menit. Pada kelompok perlakuan didaparkan rata-rata waktu ekstubasi 8,1 menit dengan nilai minimal 7,5 menit dan nilai maksimal 8,5 menit.

\begin{tabular}{|c|c|c|c|c|c|}
\hline \multirow{2}{*}{ Variabel } & \multicolumn{2}{|c|}{$\begin{array}{c}\text { Kontrol } \\
(n=15)\end{array}$} & \multicolumn{2}{|c|}{$\begin{array}{l}\text { Perlakuan } \\
\quad(n=15)\end{array}$} & \multirow[t]{2}{*}{$\begin{array}{l}\text { Nila } \\
\text { i p }\end{array}$} \\
\hline & Mean & Range & Mean & Range & \\
\hline $\begin{array}{l}\text { Lama } \\
\text { Ekstubasi } \\
\text { (menit) }\end{array}$ & 9,9 & $\begin{array}{l}9,0- \\
11,0\end{array}$ & 8,1 & $\begin{array}{c}7,5- \\
8,5\end{array}$ & $\begin{array}{c}0,000 \\
1 *\end{array}$ \\
\hline
\end{tabular}

\section{Korelasi Lama waktu extubasi dengan total kebutuhan fentanyl}

Uji normalitas telah dilakukan dengan hasil tidak normal. Sehingga digunakan rumus spearmen untuk menganalisis pengaruh total fentanyl pada lama waktu ekstubasi dengan nilai p 0,036. Pada uji korelasi didapatkan kekuatan hubungan ( $r$,coefisient correlation) sebesar 0,372 . 


\section{PEMBAHASAN}

\section{Karakteristik Subyek Penelitian}

Pada penelitian ini didapatkan kelompok kontrol maupun perlakuan sebagian besar berjenis kelamin lakilaki. Rata-rata usia pada kelompok kontrol lebih rendah dibanding kelompok perlakuan. Rata-rata IMT pada kelompok kontrol lebih besar dibanding kelompok perlakuan. Namun tidak ada perbedaan jenis kelamin, usia, dan IMT yang signifikan pada kedua kelompok $(p=1,000 ; p=0,836 ; p=0,208)$.

Berdasarkan tabel 1, sebagian besar sampel pada kelompok kontrol maupun perlakuan memiliki PS-ASA $1(53,3 \%)$. Tidak didapatkan perbedaan PS- ASA yang signifikan antara kedua kelompok tersebut $(\mathrm{p}=1,000)$. Lama operasi antara kelompok kontrol dan perlakuan juga tidak berbeda secara signifikan $(\mathrm{p}=0,368)$ dan ditampilkan pada tabel 1. Pada penelitian ini, hampir seluruh karakteristik subyek penelitian tidak memiliki perbedaan yang signifikan antara kelompok kontrol dan kelompok perlakukan. Hal ini menunjukkan kedua kelompok tersebut memiliki sifat yang homogen sehingga layak untuk dikomparasi (comparable).

\section{Komparasi Jumlah Fentanil pada Kelompok}

\section{Kontrol dan Perlakuan}

Penggunaan ketamin subdosis preemptif sinergi dengan protokol ERAS yang berbasis multimodal dan bertujuan untuk mempercepat waktu pemulihan paskaoperasi (Vuyk et al., 2015). Pada proses modulasi nyeri reseptor NMDA memiliki peran penting pada sensitisasi dan plastisitas sistem saraf pusat pada proses menerima impuls nosiseptif. Terjadinya peningkatan aktivasi reseptor NMDA berperan dalam keadaan inflamasi dannyeri neuropatik yang menyebabkan aktivasi dan eksaserbasi hiperalgesia sekunder (paskaoperasi). (Dullenkopf et al., 2011) Preemtif analgesia berperan pada blokade sensitisasi sehingga mengurangi nyeri akut (Singh et al., 2013). Ketamin merupakan antagonis reseptor NMDA yang bekerja dengan memodulasi sensorik pada sentral proses nyeri. Penelitian pada hewan dan manusia menunjukkan bahwa ketamin merupakan agen anti hyperalgesia yang poten (Radvansky et al., 2015). Ketamin merupakan adjuvan yang bermanfaat untuk mengurangi dosis analgesik yang diperlukan dan mengurangi efek samping opioid seperti mual, pusing dan efek sedasi. Hal ini yang membuat ketamin diminati sebagai salah satu strategi multimodal manajemen nyeri (Dullenkopf et al., 2011).

Pada penelitian ini didapatkan perbedaan jumlah opioid yang signifikan pada komparasi kelompok kontrol dan perlakuan. Berdasarkan tabel 5.4 didapatkan perbedaan jumlah fentanil yang signifikan $(p=0,044)$. Pada kelompok Kontrol didapatkan rata-rata penggunaan Fentanil 92 mcg dengan SD 28,3. Sedangkan pada kelompok Perlakukan didapatkan rata-rata penggunaan 71,3 mcg dengan simpangan deviasi (SD) 25,1. Belum ada penelitian sebelumnya yang menganalisis efektivitas pemberian ketamin sebagai preemptive analgesia yang mengevaluasi total pemberian fentanil, namun penelitian tentang efek analgesik kombinasi fentanyl dan ketamin oleh Tucker et al. (2015) pada 10 individu sehat menjelaskan adanya peningkatan ambang (threshold) nyeri ketika fentanyl dikombinasikan dengan ketamin dibandingkan bila tiap obat diberikan sendiri-sendiri. Hasil ini menunjukkan bahwa pemberian ketamin dapat meningkatkan efek antinosiseptif dari fentanyl. Selain itu, penambahan ketamin dosis rendah memiliki efek analgesik yang tidak meningkatkan efek sedasi (Tucker et al., 2015).

Penelitian lain oleh Singh et al. (2013) menunjukkan bahwa pemberian ketamin dosis rendah secara intravena sebelum insisi pembedahan memiliki efek preemptive terhadap nyeri pasca operasi dan menurunkan kebutuhan analgesik pada 24 jam pertama setelah operasi 
kolesistektomi laparoskopi. Pada penelitian tersebut juga dinilai VAS (visual analogue scale) dan VRS (verbal rating scale), dan hasilnya menunjukkan bahwa pada kelompok kontrol yang mendapat normal saline memiliki nilai VAS dan VRS lebih tinggi yang berarti kelompok yang mendapat

Penelitian yang dilakukan pada operasi ginekologi laparoskopi membandingkan pemberian ketamin prainsisi dan pasca operasi dengan hasil yang menunjukkan bahwa pemberian ketamin pra-insisi secara statistik menurunkan skor nyeri PACU dan konsumsi opioid maupun analgesik oral 1 minggu pasca operasi oleh (Kwok et al., 2014). Sensitisasi pada nyeri kronik terjadi karena adanya hiperalgesia sekunder akibat stimulus nyeri pada level dorsal horn. Peningkatan bidang reseptif pada dorsal horn neurons memperpanjang stimulus. Ketika stimulus diulang-ulang akan terjadi sumasi temporal dengan stimulus selanjutnya akan menyebabkan respons progresif yang lebih besar. Peningkatan efek ini menyebabkan perubahan ekspresi gen lokal dan konsentrasi second messenger yang akhirnya menyebabkan efek nyeri bertahan lama.

Reseptor NMDA berperan dalam mekanisme pencegahan nyeri kronis yang berperan pada pencegahan sensitisasi sentral dengan menggunakan preemptive analgesia. Jika analgesia diberikan sebelum stimulus noksius, maka stimulus nosiseptif tidak akan dilanjutkan ke dorsal horn, sehingga perubahan sentral dapat dicegah dan menghasilkan nyeri yang lebih ringan dan lebih singkat (Miner, 2018). Penelitian yang dilakukan oleh (Hong et al., 2016) pada pasien yang menjalani artroskopi bedah repair rotator cuff menyebutkan tidak terdapat perbedaan NRs (numeric rating scale) antara kelompok ketamin dan kontrol. Dari penelitian tersebut dapat disimpulkan bahwa pemberian ketamin sebagai preemptive tidak mengurangi nyeri pasca operasi maupun konsumsi fentanyl.
Hong et al. (2016) menyebutkan bahwa ketamin sebagai preemptive bergantung pada intensitas nyeri pembedahan dan dijelaskan bahwa pembedahan artroskopi bahu memiliki stimulus noksius yang tidak intens selama dan pasca pembedahan. Selain itu, faktor dosis pemberian ketamin yang tidak adekuat mungkin juga berperan terhadap hasil yang berbeda tersebut, namun pada penelitiannya disebutkan bahwa dosis yang digunakan cukup besar yaitu $0,5 \mathrm{mg} / \mathrm{kg}$ dibanding penelitian lain, sehingga perlu dilakukan penelitian lebih lanjut terkait dengan dosis ketamin optimal pada bedah yang sangat nyeri (Hong et al., 2016).

Analisis konsentrasi ketamin serum oleh Tucker et al. (2015) menunjukkan bahwa infus manual mungkin tidak selalu mencapai tingkat stabilitas yang dibutuhkan. Dalam penggunaan ketamin, kebutuhan ketamin perlu dikontrol dengan hati-hati. Pengaturan dosis penting dalam menghindari efek samping ketamin dan memastikan antagonisme reseptor NMDA yang memadai, serta potensiasi analgesia yang dihasilkan dari kombinasi ketamin dengan fentanyl. Fentanyl sering digunakan sebagai rescue analgesia karena sifatnya yang high-potent dan short-acting sehingga dapat digunakan berulang tanpa menyebabkan penilaian dari efikasi obat yang diteliti menjadi bias.

\section{Komparasi Waktu Ekstubasi pada Kelompok Kontrol dan Perlakuan}

Ketamin merupakan adjuvan yang bermanfaat untuk mengurangi dosis analgesik yang diperlukan dan mengurangi efek samping opioid seperti mual, pusing dan efek sedasi. Hal ini yang membuat ketamin diminati sebagai salah satu strategi multimodal manajemen nyeri (Dullenkopf et al., 2011).

Pada Studi perbandingan pengaruh ketamin oral dosis rendah dan ketamin subkutan pada pasien dengan general anesthesia yang menjalani operasi hernia inguinalis 
dengan melibatkan 90 sampel anak-anak usia 3-8 tahun menunjukkan penggunaan ketamin sebagai adjuvant mengurangi kebutuhan analgetik lain termasuk penggunaan opioid (Takzare et al., 2019).

Berkurangnya penggunaan opioid dengan penambahan preemptive ketamin diharapkan mengurangi waktu ekstubasi. Hal ini karena berkurangnya efek dari opioid pada pasein. pada tabel 3 Komparasi waktu yang dibutuhkan untuk ekstubasi pada kedua kelompok yang disampaikan didapatkan nilai $\mathrm{p}$ yang signifikan $(p<0,0001)$. Pada kelompok kontrol didaparkan rata-rata waktu ekstubasi 9,9 menit dengan nilai minimal 9 menit dan nilai maksimal 11 menit. Pada kelompok perlakuan didaparkan rata-rata waktu ekstubasi 8,1 menit dengan nilai minimal 7,5 menit dan nilai maksimal 8,5 menit. Hal ini berbeda dengan penelitian yang dilakukan oleh (Şahin \& Yasin, 2020) yang dilakukan pada 40 sampel pasien geriatri yang menjalani operasi perut dengan penggunaan preemptive low dose ketamin tidak didapatkan perbedaan bermakna pada waktu ekstubasi $(\mathrm{p}=0.136)$.

Akan tetapi pada penelitian (Abdolahi et al., 2013) didapatkan perbedaan yang signifikan waktu ekstubasi pada 88 sampel dengan ASA skor 1-2 yang menjalani operasi mata yang menyakitkan. Namun dalam penelitian itu tidak didapatkan nilai signifikan pada penggunaan opioid. Hal ini dapat dijelaskan dari mekanisme antiinflamasi yang ada pada ketamin. Inflamasi yang muncul intraoperatif ditekan oleh pemberian preemtif ketamin subdosis melalui mekanisme menekan sensitisasi nyeri di sentral. Ketamin sebagai antagonis reseptor NMDA bekerja pada efek antiinflamasi perifer yang berperan dalam mekanisme downregulation. Oleh karena persinyalan glutamat melalui reseptor NMDA dapat menghasilkan hipersensitivitas neuron sensorik tulang belakang sehingga meningkatkan sensasi nyeri, reseptor NMDA merupakan target terapeutik utama pada gangguan nyeri. Contohnya adalah ketamin yang memberikan efek analgesik dengan memblokir reseptor NMDA pada dosis sub-anestesi. (Savitz, 2020).

Selain mekanisme antiinflamasi yang berdampak pada pengurangan total opioid intraoperative, ketamin juga memiliki efek antidepresan yang dapat mengurangi waktu ekstubasi. Berkenaan dengan depresi, hipokampus tampaknya memainkan peran sentral, Kim et al menunjukkan bahwa induksi nyeri kronis pada tikus dengan adjuvan Freund menyebabkan perilaku seperti depresi bersama dengan peningkatan mediator inflamasi Penghambatan farmakologis inflamasi menghilangkan perilaku seperti depresi karena penghambatan reseptor NMDA di sumsum tulang belakang diperlukan untuk analgesia (Savitz, 2020).

Mekanisme ketamin preemtif subdosis tersebut sesuai dengan hasil penelitian yang menunjukkan pengurangan waktu ekstubasi pada subjek yang diberi perlakuan disbanding pada kontrol $(\mathrm{p}<0,0001)$. Hasil ini juga didukung penelitian lain yang menjelaskan bahwa ketamin memiliki efek neuroprotektif dengan menekan respon inflamasi terhadap pembedahan. Ketamine sebagai antagonis N-methyl-D-aspartic acid (NMDA) reseptor, mengurangi kerusakan sel saraf di korteks dengan mencegah cedera eksitotoksik dan apoptosis setelah iskemia serebral (Martinez-Gonzalez \& MartinCalvo, 2016).

Adanya perbedaan yang signifikan pada waktu ekstubasi juga dipengaruhi oleh anestesi yang bertugas. Pengalaman seorang ahli anestesi membuatnya lebih mudah untuk menentukan waktu ekstubasi tanpa bantuan alat atau parameter objektif seperti TOF. Ketersediaan alat bantu untuk menentukan waktu ekstubasi sangatlah terbatas. Penggunaannya juga biasanya dibatasi pada penelitian-penelitian yang dilakukan pada pusat Pendidikan. Waktu ekstubasi juga dipengaruhi oleh 
penggunaan agen inhalasi yang tidak termasuk dalam variabel penelitian ini.

Berkurangnya kebutuhan opioid intraopertatif pada penelitian ini secara signifikan mempercepat waktu ekstubasi pasien (p0036). Hal ini sejalan dengan penelitian (Fayaz et al., 2014) yang juga menunjukan penurunan penggunaan opioid intraopertaif juga secara signifikan mempercepat waktu ekstubasi.

\section{KESIMPULAN}

Hasil penelitian efektivitas preemptive ketamin sub dosis dalam mengurangi kebutuhan opioid durante operasi dan lama waktu ekstubasi, dapat ditarik kesimpulan sebagai berikut:

1. Pada pemberian preemptive ketamin subdosis didapatkan perbedaan jumlah pemberian fentanil yang signifikan $(p=0,044)$

2. Pada pemberian preemptive ketamin subdosis didapatkan perbedaan waktu ekstubasi yang signifikan $(p<0,0001)$

\section{UCAPAN TERIMA KASIH}

Ucapan terima kasih disampaikan kepada Universitas Muhammadiyah Surabaya yang telah memberikan pendanaan pada penelitian ini melalui hibah penelitian internal perguruan tinggi. Sehingga penelitian ini bisa terlaksana dengan baik.

\section{DAFTAR RUJUKAN}

Abdolahi, M., Soltani, H. A., Montazeri, K., \& Soleymani, B. (2013). Preemptive low-dose of ketamine does not effective on anesthetic consumption, perioperative analgesic requirement and postoperative pain, nausea and vomiting in painful ophthalmic surgery. Journal of Research in Medical Sciences: The Official Journal of Isfahan University of Medical Sciences, 18(7), 583.

Dullenkopf, A., Müller, R., Dillmann, F., Wiedemeier, P., Hegi, T. R., \& Gautschi, S. (2011). An intraoperative pre-incision single dose of intravenous ketamine does not have an effect on postoperative analgesic requirements under clinical conditions. Anaesthesia and Intensive Care, 37(5), 753-757.

Fayaz, M. K., Abel, R. J., Pugh, S. C., Hall, J. E., Djaiani, G., \& Mecklenburgh, J. S. (2014). Opioid-sparing effects of diclofenac and paracetamol lead to improved outcomes after cardiac surgery. Journal of Cardiothoracic and Vascular Anesthesia, 18(6), 742-747.

Hong, E. P., Jeong, D.-H., Kang, H. Y., Choi, J.-H., \& Park, S. W. (2016). The effect of preemptive intravenous ketamine on postoperative pain in patients undergoing arthroscopic rotator cuff repair with intra articular ropivacaine injection. Anesthesia and Pain Medicine, 11(1), 71-75.

Kwok, R. F. K., Lim, J., Chan, M. T. V, Gin, T., \& Chiu, W. K. Y. (2014). Preoperative ketamine improves postoperative analgesia after gynecologic laparoscopic surgery. Anesthesia \& Analgesia, 98(4), 1044-1049.

Martinez-Gonzalez, M. A., \& Martin-Calvo, N. (2016). Mediterranean diet and life expectancy; beyond olive oil, fruits and vegetables. Current Opinion in Clinical Nutrition and Metabolic Care, 19(6), 401.

Miner, J. R. (2018). Analgesia for the chronic pain patient. In Emergency Sedation and Pain Management (pp. 135-140). Cambridge University Press.

Motov, S., Rockoff, B., Cohen, V., Pushkar, I., Likourezos, A., McKay, C., Soleyman-Zomalan, E., Homel, P., Terentiev, V., \& Fromm, C. (2015). Intravenous subdissociative-dose ketamine versus morphine for analgesia in the emergency department: a randomized controlled trial. Annals of Emergency Medicine, 66(3), 222-229.

Radvansky, B. M., Shah, K., Parikh, A., Sifonios, A. N., Le, V., \& Eloy, J. D. (2015). Role of ketamine in acute postoperative pain management: a narrative review. BioMed Research International, 2015.

Şahin, O., \& Yasin. (2020). TİRE. Effect of Low Dose Ketamine on Postoperative Cognitive Dysfunction in Geriatric Patients Undergoing Abdominal Surgery. DÜSTAD

DünyaSă̆lıkveTabiatBilimleriDergisi, 1, 8-25.

Savitz, J. (2020). The kynurenine pathway: a finger in every pie. Molecular Psychiatry, 25(1), 131-147.

Singh, H., Kundra, S., Singh, R. M., Grewal, A., Kaul, T. K., \& Sood, D. (2013). Preemptive analgesia with ketamine for laparoscopic cholecystectomy. Journal of Anaesthesiology, Clinical Pharmacology, 29(4), 478. 
Takzare, A., A, M., M, G., AE, S., \& IG, S. (2019). A Comparative Study on the Effect of Low-Dose Oral Ketamine and Subcutaneous Ketamine on Post General Anesthesia Delirium and Pain in Children Undergoing Inguinal Hernia Surgery. Journal of Molecular Biology Research, 9(1).

Tucker, A. P., Kim, Y. I., Nadeson, R., \& Goodchild, C. S. (2015). Investigation of the potentiation of the analgesic effects of fentanyl by ketamine in humans: a double-blinded, randomised, placebo controlled, crossover study of experimental pain [ISRCTN83088383]. BMC Anesthesiology, 5(1), $1-12$.

Vuyk, J., Sitsen, E., \& Reekers, M. (2015). Intravenous anesthetics. Miller's Anesthesia, 8, 858 .

Cite this article as: Septiyawan, $R, B$., Susila, D., Sunarsono $S$. (2021). Efektivitas Preemtif Ketamin Subdosis Dalam Mengurangi Kebutuhan Opioid Intraoperatif Dan Waktu Ekstubasi. Jurnal Ilmiah Media Husada. 10(2), 88-98.

https://doi.org/10.33475/jikmh.v7i2.21 